OPEN ACCESS

Edited by:

Maria S. Tapia,

Academia de Ciencias Físicas,

Matemáticas y Naturales de

Venezuela, Venezuela

Reviewed by:

Felix Moronta-Barrios,

International Centre for Genetic

Engineering and Biotechnology, Italy Alejandro J. Pieters,

University of Hohenheim, Germany

${ }^{*}$ Correspondence:

Edgloris Marys

edgloris@gmail.com

Specialty section:

This article was submitted to

Agro-Food Safety,

a section of the journal

Frontiers in Sustainable Food Systems

Received: 27 May 2021 Accepted: 11 October 2021 Published: 03 November 2021

Citation:

Marys E and Rosales LC (2021) Plant Disease Diagnostic Capabilities in Venezuela: Implications for Food

Security.

Front. Sustain. Food Syst. 5:715463. doi: 10.3389/fsufs. 2021.715463

\section{Plant Disease Diagnostic Capabilities in Venezuela: Implications for Food Security}

\author{
Edgloris Marys ${ }^{1 *}$ and Ligia Carolina Rosales ${ }^{2}$ \\ ${ }^{1}$ Laboratorio de Biotecnología y Virología Vegetal, Centro de Microbiología y Biología Celular, Instituto Venezolano de \\ Investigaciones Científicas (IVIC), Caracas, Venezuela, ${ }^{2}$ Departamento de Protección Vegetal, Centro Nacional de \\ Investigaciones Agropecuarias (CENIAP), Instituto Nacional de Investigaciones Agrícolas (INIA), Maracay, Venezuela
}

Venezuela is currently experiencing the most severe humanitarian crisis in the Americas of this century. Little food is being produced locally, despite the population's right to food. Plant disease outbreaks are causing substantial declines in major staple food and cash crops, and this impacts on rural livelihoods, and poses a significant and growing threat to the already complex food insecurity crisis in the country. Nonetheless, phytosanitary services and hence the control of plant pests and diseases have been substantially weakened over the recent years as a consequence of the collapse of the economy and the substantial deterioration of government services. Therefore, most of the pathogens associated with symptoms-causing diseases remain unidentified or uncharacterized, and no surveillance or crop protection strategies have been implemented. In this review, we address the country's issues and challenges in diagnosing, monitoring and managing plant diseases to restore national food security.

Keywords: plant health, pathogen detection, diagnostics, food security, phytosanitary system, Venezuela

\section{INTRODUCTION}

Venezuela is experiencing a profound humanitarian emergency that has led more than 9.3 million people (a third of the population) to be acutely food insecure and in need of assistance since JulySeptember 2019 [World Food Program (WFP), 2019], making this the current fourth-largest food crisis in the world (Global Network Against Food Crises, 2020). The current state of hunger in Venezuela is a result of multiple societal collapses. From 1999 to date, the transition from a capitalist to a socialist State-centered mode of production impaired agricultural and food production systems (reviewed in Rodríguez-García, 2021). The situation is now aggravated by the total collapse of public services, fuel shortages, and by the impact of the global COVID-19 pandemic which has affected logistics and agricultural activities across the country (FAO and WFP, 2020).

Access to agricultural production data in Venezuela has been restricted by government agencies in recent years. Official figures record an average $27 \%$ shortage and fall in agricultural production between 1999 and 2014, while other figures report 70\% drop (RodríguezGarcía, 2021). According to The Confederation of Agricultural Producers Associations of Venezuela (FEDEAGRO), between 2009 and 2018 the production of strategic agricultural commodities like rice decreased by $50.9 \%$ and corn 55.9\% (Gutierrez, 2019) (Figure 1). The low productivity is caused by shortage of agricultural supplies (seeds, fertilizers, agrochemicals, etc) and other factors (Tapia et al., 2017). This review raise the issue of crop losses due to pathogens, linked to the dismantling of the plant diagnostic network across the country. 

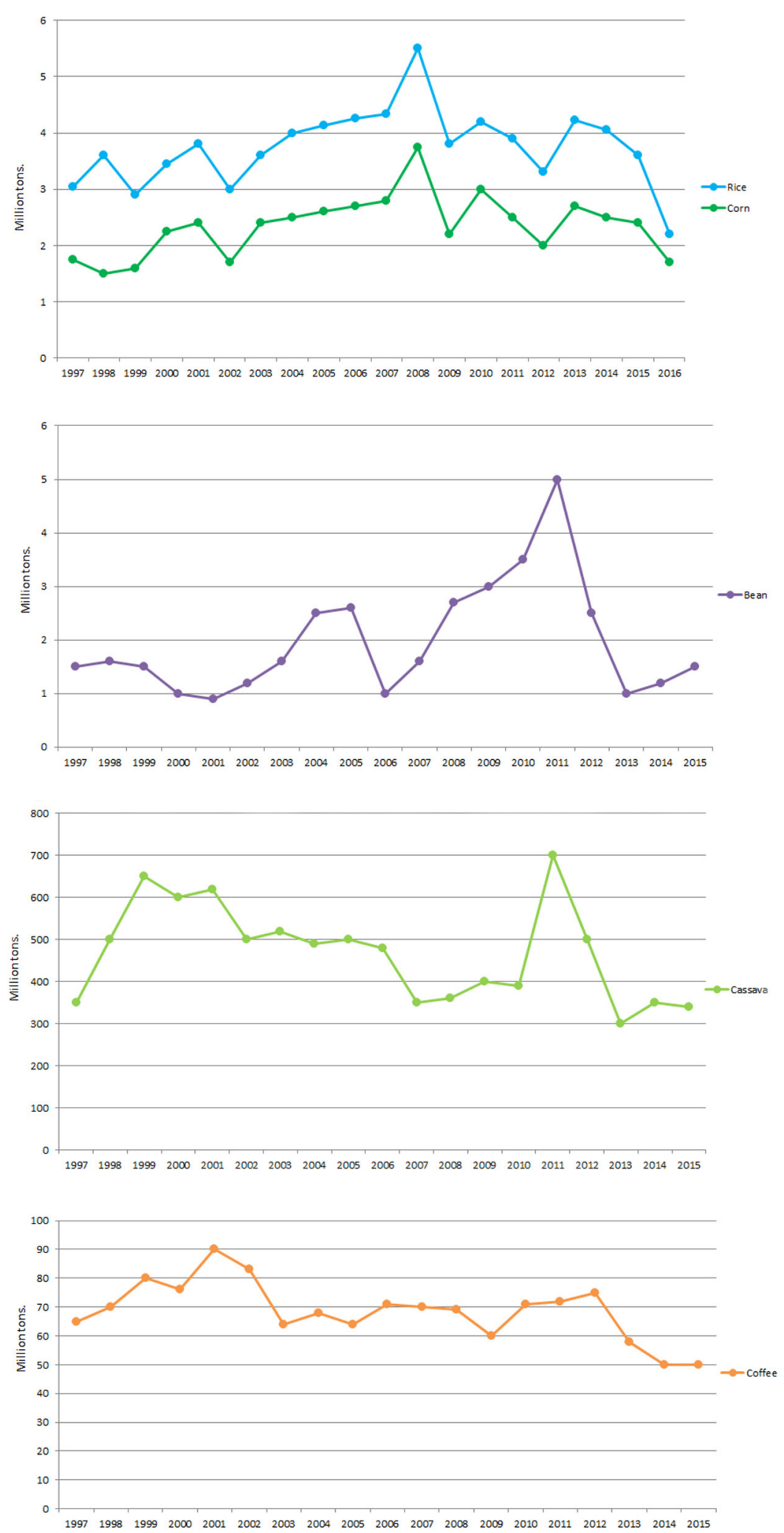

FIGURE 1 | Production of principal crops in Venezuela in the period 1997-2015. Source: FEDEAGRO (Confederación de Productores Agropecuarios de Venezuela), 2017. 
The emergence of novel plant pathogens, as well as the expansion of the geographic range of known pathogens are causing a significant disruption in food production, threatening livelihoods of people depending on these crops for their income. Although quantification of crop losses due to pathogens in Venezuela is limited, symptoms associated with rice leaf and panicle blight, potato moth, coffee rust, wilts of banana and cacao frosty pod, have been reported to have caused important crop losses in each crop (González et al., 2011; Sequera, 2019; Martínez-Solórzano et al., 2020). The ongoing outbreak of citrus huanglongbing (HLB) caused by a bacterial pathogen, has devastated the national citrus industry (Marys et al., 2021). Other invaders are in the horizon: the recent arrival of the transboundary disease "Fusarium wilt," tropical race $4(\mathrm{R} 4 \mathrm{~T})$ in the Colombian Guajira near the Venezuelan border, could heavily damage national banana and plantain plantations. Regulatory command of plant health services to reduce the risk of new and emerging threats to crops should ideally involve accurate detection, reliable surveillance and immediate intervention (Miller et al., 2009). However, due to a lack of investment in basic research and the dismantling of the national plant health network, most of the pathogens associated with symptoms causing diseases remain unidentified or poorly characterized. The goal of this article is to provide a perspective on the current status of the capacities for plant diagnostics in Venezuela.

\section{THE VENEZUELAN PLANT HEALTH SYSTEM: BRIEF OVERVIEW}

The plant health system in Venezuela has evolved under the influence of deep changes in the country's political and economic situation, as well as external international trends. From 1947 to 1952 the country was moving away from a traditional agricultural system, from isolated family farms (conucos) toward a modern, mechanized system with new and expensive equipment and large mono-cultivated estates. With this new era of agricultural development came new phytopathological problems. At that time, many phytopathologists under the auspices either of the Venezuelan government or their own countries, devoted their time and effort to the recently created Plant Pathology Department of Maracay, which was the only phytopathology center in Venezuela. Then, the creation of the National Centre for Agricultural Research (CENIAP, which is now part of the National Institute for Agricultural Research, INIA), established the first official plant health service with Sanitary Police and Phytopathological Supervision Services in 1950 (Malaguti, 1990).

In 1993, the plant health service was restructured as the Autonomous Agricultural Health Service (SASA), which was the governing body of solid agricultural health policies, serving as the country's National Plant Protection Organization (NPPO). The role of the SASA was to ensure phytosanitary protection by organizing plant quarantine, plant protection (phytosanitary surveillance, phytosanitary emergencies, and response plans), surveillance and maintenance of pest free areas and areas of low pest prevalence; conducting pest risk analyses; ensuring the maintenance of phytosanitary security of consignments after certification and staff training [SASA (Servicio Autónomo de Sanidad Agropecuaria), 1993]. The SASA in collaboration with individual state departments of agriculture, research institutes and laboratories including the INIA, agricultural universities (UCV, ULA, LUZ, UCLA), the Institute of Advanced Studies (IDEA) and the Venezuelan Institute for Scientific Research (IVIC) developed a coordinated, robust diagnostic network that shared expertise and technical capacity and served national plant protection services in the country. Then in 2008 a new law replaced the SASA by the National Institute of Integral Agricultural Health (INSAI), which became the governing body regulated by the Ministry for Productive Agriculture and Land (MPPAT) (República Bolivariana de Venezuela, 2008). As a result the institutional framework governing plant health descended into sectarianism and politicization, and resulted in dismantling of major institutions that aimed to ensure plant protection (see below). As a consequence a number of epidemiological surveillance, diagnostics, management and germplasm health programs were abandoned (Enríquez, 2013). A new collective of 18 plant disease and pest diagnostic facilities known as the National Plant Health Laboratories Network (Red Nacional de Laboratorios de Salud Vegetal, RNLSV), was established with presence across the country to provide scientific and technical support to the INSAI [INSAI (Instituto Nacional de Salud Agrícola Integral), 2008]. However, the challenge of equipping the new units and training new diagnosticians was never truly met. Unfortunately, the decline in oil prices and erratic macroeconomic policies caused, particularly from 2008, a deep socioeconomic and institutional collapse, from which the plant health system did not escape.

\section{PLANT DIAGNOSTIC LABORATORIES: AN EXPLORATORY CAPACITY EVALUATION}

In order to document the status of plant diagnostic laboratories (PDLs) capabilities, we made an exploratory survey of active diagnosticians affiliated with PDLs from June 11 to July 2, 2020. Participation was solicited through an email with a link to a questionnaire in Google Form (one respondent per PDL). Survey responses of 18 diagnosticians assessing their perceived levels on the availability and quality of public services they are able to provide, their equipment, human resources and funding are shown in Table 1. The results showed that physical infrastructure, equipment, reagents and the lack of human resources were all obstacles to plant protection work. The crisis has affected the provision of basic services: most network facilities have critical shortages in electric, water and gas supply and lack electricity generators and water purification systems. Infrastructure is in a critical condition. Transportation infrastructure has notoriously deteriorated after years of disinvestment and little maintenance, hampering mobility and surveillance. This is now aggravated by fuel shortages in the country. Internet access is also very limited in most facilities. Currently, most laboratories have either obsoleted or a complete lack of low-temperature freezers, reducing storage capacity and reference collection maintenance. Only a very few laboratories are stocked with minimal equipment 
TABLE 1 | Survey respondents' rating of the exploratory phytosanitary capacity evaluation.

\begin{tabular}{|c|c|c|c|}
\hline & Absent & Inadequate & Adequate \\
\hline \multicolumn{4}{|l|}{ Laboratory/Institution services } \\
\hline Water supply & $39 \%(7)$ & $61 \%(11)$ & $0 \%(0)$ \\
\hline Electrical supply & $11 \%(2)$ & $89 \%(16)$ & $0 \%(0)$ \\
\hline Electric generators & $94 \%(17)$ & $0 \%(0)$ & $6 \%(1)$ \\
\hline Gas supply & $22 \%(4)$ & $72 \%(13)$ & $6 \%(1)$ \\
\hline Internet access & $17 \%$ (3) & $39 \%(7)$ & $44 \%(8)$ \\
\hline DNA sequencing/bioinformatic analysis facility & $100 \%$ & $0 \%(0)$ & $0 \%(0)$ \\
\hline Reference collections & $83 \%(15)$ & $17 \%(3)$ & $0 \%(0)$ \\
\hline \multicolumn{4}{|l|}{ Laboratory/Institution equipment } \\
\hline Low temperature storage capacity & $22 \%(4)$ & $78 \%(14)$ & $0 \%(0)$ \\
\hline Autoclave & $17 \%(3)$ & $50 \%(9)$ & $33 \%(6)$ \\
\hline Water purification /distillation systems & $16 \%(3)$ & $66 \%(12)$ & $16 \%(3)$ \\
\hline Glassware & $0 \%(0)$ & $100 \%(18)$ & $0 \%(0)$ \\
\hline Plastic ware & $0 \%(0)$ & $100 \%(18)$ & $0 \%(0)$ \\
\hline $\mathrm{pH}$ meters & $22 \%(4)$ & $78 \%(14)$ & $0 \%(0)$ \\
\hline Gel electrophoresis systems & $38 \%(7)$ & $44 \%(8)$ & $16 \%(3)$ \\
\hline Incubators & $33 \%(6)$ & $56 \%(10)$ & $11 \%(2)$ \\
\hline Spectrophotometers & $44 \%(8)$ & $50 \%(9)$ & $6 \%(1)$ \\
\hline Ice-making machines & $34 \%(6)$ & $66 \%(12)$ & $0 \%(0)$ \\
\hline Balances & $22 \%(4)$ & $39 \%(7)$ & $39 \%(7)$ \\
\hline PCR-machines & $38 \%(7)$ & $44 \%(8)$ & $16 \%(3)$ \\
\hline ELISA plate readers & $78 \%(14)$ & $11 \%(2)$ & $11 \%(2)$ \\
\hline Reagents and laboratory chemicals & $28 \%(5)$ & $72 \%(13)$ & $0 \%(0)$ \\
\hline Light microscopes & $17 \%(3)$ & $11 \%(2)$ & $72 \%(13)$ \\
\hline Electron microscopes & $34 \%(6)$ & $55 \%(10)$ & $11 \%(2)$ \\
\hline \multicolumn{4}{|l|}{ Human Resources } \\
\hline Human capital & $0 \%(0)$ & $94 \%(17)$ & $6 \%(1)$ \\
\hline Training & $17 \%(3)$ & $83 \%(15)$ & $0 \%(0)$ \\
\hline \multicolumn{4}{|l|}{ Funding } \\
\hline Government & $0 \%(0)$ & $100 \%(18)$ & $0 \%(0)$ \\
\hline Other agencies & $94 \%(17)$ & $6 \%(1)$ & 0\% (0) \\
\hline
\end{tabular}

commonly used for diagnostic methods in plant pathology, such as Enzyme-Linked Immunosorbent-Assay (ELISA), transmission electron microscopy, and Polymerase Chain Reaction (PCR)based assays; however, the impossibility to perform preventive maintenance leads to equipment's failure. Financial constrains limit the purchase of modern equipment in most laboratories, while supplies and reagents for routine microbiological culture are scarce (reviewed in Requena, 2010; Tapia et al., 2017).

In the past decade, pathogen detection methods throughout the world have swiftly advanced and diversified. In our survey, we asked diagnosticians to indicate which methods they used (Table 2). We found that traditional plant diagnostic methods, such as microscopic observation continue to be commonplace in PDLs, while bioassays, culturing and serological tests were less frequent. This could be explained by the lack of basic services for greenhouse maintenance and financial restraints to acquire supplies and reagents for pathogens culture and serology. Among molecular techniques, PCR is being used by $27 \%$ of the respondents, while more expensive techniques such
TABLE 2 | Percentage of plant diagnostic laboratories using diagnostic methods, determined by the diagnostician survey 1 .

\begin{tabular}{lc}
\hline Method & Percentage of PDLs that use the method1 \\
\hline Bioassay & $22 \%(4)$ \\
Biochemical & $33 \%(6)$ \\
Light microscopy & $77 \%(14)$ \\
TEM & $16 \%(3)$ \\
Immunologic & $22 \%(4)$ \\
PCR & $27 \%(5)$ \\
qPCR & $0 \%(0)$ \\
RT-PCR & $11 \%(2)$ \\
Multiplex PCR & $0 \%(0)$ \\
Sequencing & $5 \%(1)$ \\
LAM & $0 \%(0)$ \\
Next-Gen sequencing & $0 \%(0)$ \\
\hline
\end{tabular}

as quantitative PCR and next generation sequencing are out of reach. Less costly tests utilizing isothermal amplification techniques have not been adopted. Due to the lack of genomic laboratory service at local level, some researchers in Venezuela often send genomic materials (DNA and RNA) for genomic analysis abroad (e.g., to Europe). This is not just costly but time-wasting and inefficient.

\section{THE PHYTOSANITARY STATUS OF TOP CROPS IN VENEZUELA}

Active phytopathologists working in private practice, diagnostic laboratories, universities (research and extension) and agricultural consulting companies were asked to respond to a rapid online survey on the most prevalent diseases in strategic crops observed during 2020 (Figure 2). Rice leaf and panicle blight, bacterial and fungal wilts of banana, citrus huanglongbing (HLB) and fall armyworm pest on maize ranked among the most recorded diseases.

\section{Rice Leaf and Panicle Blight}

During 2011, rice (Oryza sativa) farmers complained about near $50 \%$ decline in production, associated to low grain yield caused by low grain filling, low fertility and low grain weight. The disease is referred to as "vaneamiento" (panicle blight). Pathogens isolated from disease panicles during sample collections were Fusarium and Curvularia, while bacterial genus Pantoea was isolated from $95 \%$ of samples, using pathogen culture, microscopic observation and biochemical methods (A. González, personal communication, July 21, 2020). Molecular methods (PCR) were used in order to identify Burkholderia glumae from diseased rice showing severe leaf and panicle blight during dry production seasons between 2009 and 2011 with 45-100\% incidence (González et al., 2011), within collaborative research between DANAC Foundation for Agriculture Research in Venezuela and the International Center for Tropical Agriculture (CIAT) in Colombia. Actually, the disease affects all the major rice-growing regions of Venezuelan and is expected to contribute to the lowest 


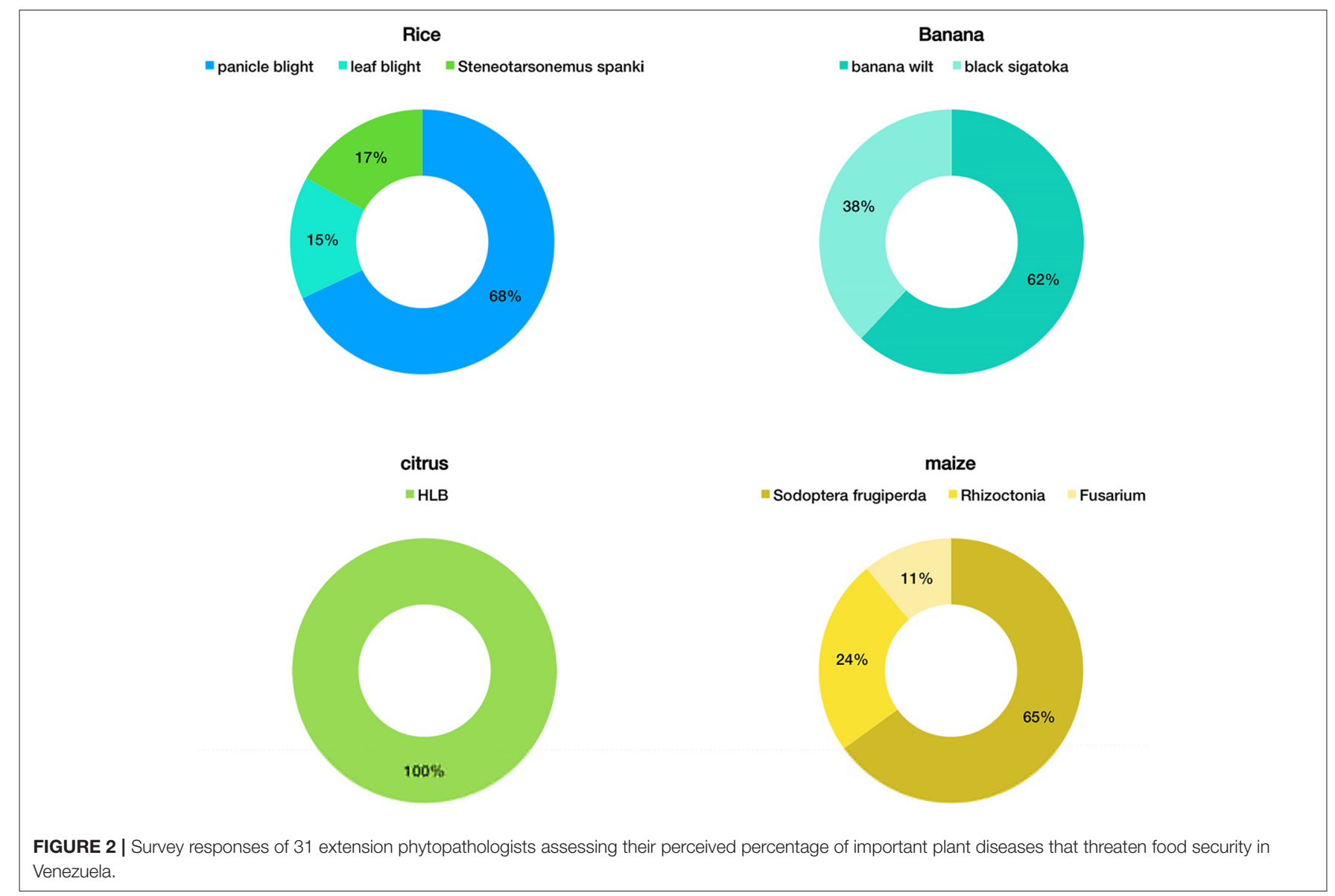

output of rice since 1972 (FAOstats, 2020). Recent national efforts toward the molecular characterization of fungi and bacteria associated with rice and panicle blights have been stopped due to the lack of resources.

\section{Bacterial and Fungal Wilts of Banana}

Emerging fungal disease outbreaks of "Black Sigatoka" (BS), caused by Mycosphaerella fijiensis Morelet [anamorph: Pseudocercospora fijensis (Morelet) Deighton] and of "Fusarium wilt of banana," caused by Fusarium oxysporum f. sp. cubense (Foc) were associated with near 50\% production decline and subsequent collapse of the export trade from Sur del Lago in 1991 and 2007 (Pineda et al., 1997; Martínez-Solórzano et al., 2020). A recent survey of the current and potential phytopathological problems in banana from inspections done during 2017-2019 in Sur del Lago, revealed a high incidence of BS (90\%), Foc (36\%) and Moko, caused by bacteria Ralstonia solanacearum (16\%) (Martínez-Solórzano et al., 2020). Nationwide control of banana wilt diseases has been mainly based on frequent applications of chemicals, although there is no chemical control for Foc and there are limited other options for managing this disease (Aular and Casares, 2011). Due to the scarcity of agrochemicals and to disruption of phytosanitary public services such as extension diagnostic, monitoring and surveillance during the crisis period in the country, the incidence of diseases is expected to rise significantly beyond those reported, threatening national production. It is notable that BS, Foc and Moko were detected and surveyed using only conventional diagnosis methods, including symptomatology and morphology (Pineda et al., 1997; Rodríguez, 2000). To our knowledge, no information exists on the molecular population structure or genetic diversity of BS/Foc in this country.

Recently, the transboundary disease "FW Tropical race 4" (Foc TR4), a lethal variant of Foc that kills banana, plantains and other Musa species, was detected in La Guajira, northeast of Colombia, next to Zulia state (Colombia-Venezuela border) (García-Bastidas et al., 2020). The arrival of Foc TR4 to the Americas has triggered an enormous pressure on the regional plant protection agencies in Latin America. One year before, in 2018, the INSAI issued an administrative ruling on Foc TR4 prevention and management [INSAI (Instituto Nacional de Salud Agrícola Integral), 2018]. However, the country was poorly prepared and lacked the resources required to comply with this regulatory framework. The risk of introduction of Foc TR4 is very high because the Venezuelan migrants travel on foot back and forth across the frontier through La Guajira due to the COVID19 pandemic. Also, banana smuggling and trafficking between the two countries, although denounced by SVIAA's agronomists, and despite the INSAI regulations (Palomares, 2020). Illegal trade could also lead to the entry of Foc TR4. Phytosanitary authorities 
should step up farm biosecurity measures and border controls to prevent it, as it could mean the disappearance of one of the main elements of the Venezuelan diet.

\section{Citrus Huanglongbling (HLB)}

At the beginning of the 21st century, huanglongbing (HLB) emerged as the most destructive citrus disease and the single main threat to the future of the world citrus industry (Bové, 2006). In October 2016, first reports of early HLB-like symptoms such as leaf yellowing and yellow shoots in trees in Aragua state were alerted by citrus producer organizations and issued by researchers working at INIA to the respective phytosanitary authorities (Morales and Schmidt, 2016). The early detection of HLB is based on molecular, PCR methods, and it is one of the cornerstones for preventing incursion into disease-free countries. However, early and accurate diagnosis was not performed due to the lack of materials needed to conduct PCR tests in the country. Then in August 2017, the crop failed dramatically, and recurrent demands from citrus producers facing heavy crop losses forced the phytosanitary authorities (INSAI) to respond. International scientific cooperation among Venezuelan plant pathologists abroad, the Inter-American Institute for Cooperation on Agriculture (IICA) in Venezuela allowed the purchase of oligonucleotides and reagents needed for the molecular detection of HLB. The disease was diagnosed and exotic pest alert outbreak was issued by the INSAI (República Bolivariana de Venezuela, 2017). However, institutional approaches to plant health failed, and rules to prevent HLB spread were not established in the country. One year after the first reports of symptoms, HLB was widespread in the main citrus-producing states with an overall high incidence (Marys et al., 2021). As a result, citrus production has declined from 2016 to the present by more than $90 \%$ [FEDEAGRO (Confederación de Productores Agropecuarios de Venezuela), 2020]. According to fruit growers' associations, only $5 \%$ of the 35.000 hectares planted with citrus in Venezuela continued to exist in high mountain range Andean by 2020 [FEDEAGRO (Confederación de Productores Agropecuarios de Venezuela), 2020]. The disease not only reduced the availability of citrus fruits, but is also threatening the livelihoods of people depending on citrus crop for their income. The citrus industry landscape is uncertain in the actual context of the economical and institutional crisis. At this time hundreds of farms are no longer productive and have been abandoned. Some farmers have switched to the cultivation of other crops in order to salvage their livelihoods.

\section{Maize Pests and Diseases}

During 2020, major outbreaks of armyworms (Spodoptera frugiperda) were reported in many maize fields in Venezuela, with estimates of $20-50 \%$ yield loss (Colmenárez, 2020). Amid fuel and chemical shortages, and COVID-19 pandemic spread, controlling the pest has become even more difficult, representing a significant threat to food security and livelihoods.

Phytopathologists also identified symptoms associated with Rhizoctonia and Fusarium. However, very few investigations have been carried out on the molecular genetic characterization of the fungal population in maize in Venezuela (González-Vera et al., 2010).

\section{Prospects}

The globalization of trade, human mobility, climate change, pathogen and vector evolution, and political instability all combine to create a global environment with the increasing risk to food security. The social and economic consequences of the failure to recognize, contain, and/or control threatening plant pathogens require that every effort be made to engage in efficient and effective programs of surveillance, diagnosis, and detection (Miller et al., 2009). The development of a strong initiative in plant health in Venezuela is hampered by gaps in several critical areas, mainly due to the dismantling of the national plant health network. It is key to identify concrete strategic partnerships, both national and international, to boost the restoration of plant health research capacities in the country. Funding gaps could be bridged through publicprivate and donor partnerships with proper maintenance and supervision to invest in the improvement of scientific research by stocking and refurbishing pre-existing laboratories. A case in point was the huge investment made by Inter-American Bank of Development and the FONACIT (National Found for Science and Technology) in the biotechnology sector in Venezuela in the early 2000s [FONACIT (Fondo Nacional de Ciencia y Tecnología e Innovación), 2007; Tapia et al., 2017]. As a result, one of the authors (Marys) received funding for the development of a network for plant virus diagnostics. That investment allowed plant virology laboratories to adopt what were state-of-the-art technologies at the time for plant diagnostic (ELISA and PCR) for routine use. Unfortunately, the projects were not continued due to the lack of institutional support, which lead to the obsolescence of equipment and breakup of the network (Tapia et al., 2017). However, at least two of these laboratories retain certain baseline capacity (IVIC, UCV).

The accurate identification of causative agents is the foundation of phytopathology and the resolution of different methods, especially modern techniques, is an important consideration for plant disease epidemiology and diagnostics (Elshire et al., 2011). Therefore, genomic and bioinformatic approaches should be adopted in Venezuela. Investment in human resource capacity is desperately needed in the country. It is well-documented that Venezuela has lost $16 \%$ of its scientific research force through emigration mainly in recent years (Diez et al., 2021). Researchers in agricultural sciences accredited in PEII (Research Stimulus Program) accounted for $23 \%$ of all knowledge areas in 2012, falling to $11 \%$ in 2015 (Tapia et al., 2017). Graduate programs should emphasize training in applied plant pathology with a good foundation in molecular biology. Strengthening relations with the diaspora of researchers in plant pathology could allow the creation of fellowship-style programs that house Venezuelan researchers in universities abroad.

The spread of invasive plant pathogens in Venezuela is a growing emergency of national and regional scale, with pervasive and long-lasting harmful effects on food 
supplies and livelihoods. This review is a call for action. There is a compelling need for integrated and coordinated responses at national, regional and international levels that aim to reduce the national gap in early and accurate plant pathogens diagnosis.

\section{DATA AVAILABILITY STATEMENT}

The raw data supporting the conclusions of this article will be made available by the authors, without undue reservation.

\section{REFERENCES}

Aular, J., and Casares, M. (2011). Consideraciones sobre la producción de frutas en Venezuela. Revista Brasileira de Fruticultura 33, 187-198. doi: 10.1590/S0100-29452011000500022

Bové, J. M. (2006). Huanglongbing: a destructive, newly emerging, century-old disease of citrus. J. Plant Pathol. 8, 7-37. doi: 10.4454/jpp.v88i1.828

Colmenárez, M. (2020). Portuguesa, Brote de gusanos cogolleros barredores amenaza 50.000 hectáreas de maíz. Available online at: https://elpitazo.net/losllanos/portuguesa-brote-de-gusanos-barredores-amenaza-50-000-hectareasde-maiz/ (accessed May 26, 2020)

Diez, E., Freites, Y., García-Pérez, M., Ordoñez, L., Pineda, J., Requena, J., et al. (2021). Venezuelan research community migration: impacts and public policy implications. Interciencia 46, 1-49. doi: 10.18235/0002776

Elshire, R. J., Glaubitz, J. C., Sun, Q., Poland, J. A., Kawamoto, K., Buckler, E. S., et al. (2011). A robust, simple genotyping-bysequencing (GBS) approach for high diversity species. PLoS ONE 6:e19379. doi: 10.1371/journal.pone.0019379

Enríquez, L. (2013). The paradoxes of Latin America's 'pink tide': venezuela and the project of agrarian reform. J. Peasant Stud. 40, 611-638. doi: $10.1080 / 03066150.2012 .746959$

FAO and WFP (2020). FAO-WFP Early Warning Analysis of Acute Food Insecurity Hotspots. Rome.

FAOstats (2020). Available online at: http://www.fao.org/faostat/en/ (accessed December 14, 2020).

FEDEAGRO (Confederación de Productores Agropecuarios de Venezuela) (2017). Available online at: www.fao.org/faostat/en/\#home (accessed December 14, 2020).

FEDEAGRO (Confederación de Productores Agropecuarios de Venezuela) (2020). Ubican en $90 \%$ caída de la producción de cítricos en el país (online). Available online at: https://bit.ly/3qsctwF (accessed February 11, 2021).

FONACIT (Fondo Nacional de Ciencia y Tecnología e Innovación) (2007). Biotecnología. En Registro, N 342. Caracas: Minsiterio del Poder Popular para Ciencia y Tecnología.

García-Bastidas, F. A., Quintero-Vargas, J. C., Ayala-Vasquez, M., Schermer, T., Seidl, M. F., Santos-Paiva, M., et al. (2020). First report of fusarium wilt tropical race 4 in Cavendish bananas caused by Fusarium odoratissimum in Colombia. Plant Dis. 104:994. doi: 10.1094/PDIS-09-19-1922-PDN

Global Network Against Food Crises (2020). 2020 Global Report on Food Crises: Joint Analysis for Better Decisions. Available online at https://www.wfp.org/ publications/2020-global-report-food-crises (accessed February 13, 2021).

González, A., Graterol, E., Arnao, E., Torres, E., Acevedo, M., and Mosquera, G. (2011). Primer reporte de Burkholderia glumae causante de la pudrición bacteriana de la panícula del arroz en Venezuela. Fitopatologia Colombiana 35:81.

González-Vera, A., Bernardes-de-Assis, J., Zala, M., McDonald, B., CorreaVictoria, F., Graterol-Matute, E., et al. (2010). Divergence between sympatric rice-and maize- infecting populations of Rhizoctonia solani AG-1 IA from Latin America. Phytopathology 100, 172-182. doi: 10.1094/PHYTO-100-20172

\section{AUTHOR CONTRIBUTIONS}

All authors listed have made a substantial, direct and intellectual contribution to the work, and approved it for publication.

\section{ACKNOWLEDGMENTS}

The authors wish to thank numerous research colleagues for sharing theirs insights, two reviewers for useful discussions and refining our manuscript and Dr. Adrian Gibbs for helpful comments. Our special gratitude to the editor for helpful advice.

Gutierrez, A. (2019). La situación agroalimentaria en Venezuela: hacia una nueva estrategia. Revista Foro. 3, 31-52.

INSAI (Instituto Nacional de Salud Agrícola Integral) (2008). La institución. Available online at: http://www.insai.gob.ve/?page_id=82 (accessed May 26, 2020).

INSAI (Instituto Nacional de Salud Agrícola Integral) (2018). Comunicado sobre riesgo fitosanitario trasfronterizo. Available online at: http://www.insai.gob. ve/wp-content/uploads/2019/08/comunicado-fronterizo-21-08-2019.pdf (accessed May 26, 2020).

Malaguti, G. (1990). Half a century of a plant pathologist in a tropical country -Venezuela. Annu. Rev. Phytopathol 28, 1-11. doi: 10.1146/ annurev.py.28.090190.000245

Martínez-Solórzano, G., Rey-Brina, J., Rodríguez, D., Jiménez, C., Rodríguez, Y., Rumbos, R., et al. (2020). Análisis de la situación fitopatológica actual de las musáceas comestibles en Venezuela. Agronomía Trop. 70, 1-20. doi: 10.5281 /zenodo.4323273

Marys, E., Mejías, R., Rodríguez-Román, E., Mejías, A., and Mago, M. (2021). Citrus huanglongbing in Venezuela: partial distribution and the relative incidence of Candidatus Liberibacter asiaticus in central-northern states. Agronomía Trop. 71:e4605364. doi: 10.5281/zenodo.4605384

Miller, S. A., Beed, F. D., and Harmon, C. L. (2009). Plant disease diagnostic capabilities and networks. Annu. Rev. Phytopathol. 47, 15-38. doi: 10.1146/annurev-phyto-080508-081743

Morales, P., and Schmidt, A. (2016). Informe técnico sobre sospecha de HLB en muestras de plantas de naranja provenientes de ramas de árboles de naranja 'Valencia', Parcela 33 Colonia Guayabita. Instituto Nacional de Investigaciones Agrícolas, Centro Nacional de Investigaciones Agropecuarias. Gerencia de Investigación, Maracay, Venezuela.

Palomares, S. (2020). Productores denuncian ingreso de contrabando de plátano desde Colombia. Available online at: https://www.vidaagro.com. ve/especialvidaagroproductores-denuncian-ingreso-de-contrabando-deplatano-desde-colombia-4/ (accessed May 26, 2020).

Pineda, J., Carrasco, A., Cardona, R., and Cooz, R. (1997). Presencia de la Sigatoka negra (Mycosphaerella fijiensis) en las principales zonas plataneras de Venezuela. Bioagro 9, 52-60.

República Bolivariana de Venezuela (2008). Gaceta Oficial Extraordinaria N 5.899. Available online at: http://extwprlegs1.fao.org/docs/pdf/ven83198.pdf (accessed August 18, 2020).

República Bolivariana de Venezuela (2017). Gaceta Oficial Extraordinaria N 41.248. Available online at: http://ipcc.int/es/countries/venezuela-boivarianrepublic-of/pestreports/2018/06/reporte-de-plagas/ (accessed September 13, 2021).

Requena, J. (2010). Science meltdown in Venezuela. Interciencia 35, 437-444. Available online at: https://www.interciencia.net/wp-content/uploads/2018/01/ 437-REQUENA-8.pdf (accessed October 10, 2020)

Rodríguez, D. (2000). Ocurrencia de Fusarium oxysporum en plantaciones de “cambur Manzano" en el estado Trujillo. Fitopatol. Venez. 13, 22-24.

Rodríguez-García, J. J. (2021). Food security in Venezuela: from policies to facts. Front. Sustain. Food Syst. 5:617907. doi: 10.3389/fsufs.2021.617907 
SASA (Servicio Autónomo de Sanidad Agropecuaria) (1993). Legislación fitosanitaria de Venezuela (Compendio). Colina RJ (comp). Ministerio de Agricultura y Cría. Caracas, Venezuela.

Sequera, V. (2019). Amid Malnutrition, Crop Diseases Pose Threat to Venezuela Food Supplies. Available online at: https://cn.reuters.com/article/us-venezuelacrops-idUSKBN1ZS1VJ (accessed May 26, 2020).

Tapia, M. S., Puche, M., Pieters, A., Marrero, J. F., Clavijo, S., Gutiérrez, A., et al. (2017). "Food and nutritional security in Venezuela. The agrifood abduction of a Country: vision and commitment" in Challenges and Opportunities for Food and Nutrition Security in the Americas: The View of the Academies of Sciences, eds M. Clegg, E. Bianchi, J. McNeil, L. Herrera, and K. Vammen (Mexico: The Inter American Network of Academies of Sciences. The Federal Ministry of Education and Research. German National Academy of SciencesLeopoldina), 566-607.

World Food Program (WFP) (2019). Venezuela Food Security Assessment. Main Findings. Available online at: https://reliefweb.int/report/venezuelabolivarianrepublic/wfp-venezuela- evaluaci-n-de-seguridad-alimentariaprincipales (accessed October 10, 2020).
Conflict of Interest: The authors declare that the research was conducted in the absence of any commercial or financial relationships that could be construed as a potential conflict of interest.

Publisher's Note: All claims expressed in this article are solely those of the authors and do not necessarily represent those of their affiliated organizations, or those of the publisher, the editors and the reviewers. Any product that may be evaluated in this article, or claim that may be made by its manufacturer, is not guaranteed or endorsed by the publisher.

Copyright $\odot 2021$ Marys and Rosales. This is an open-access article distributed under the terms of the Creative Commons Attribution License (CC BY). The use, distribution or reproduction in other forums is permitted, provided the original author(s) and the copyright owner(s) are credited and that the original publication in this journal is cited, in accordance with accepted academic practice. No use, distribution or reproduction is permitted which does not comply with these terms. 